\title{
Effectiveness of Entrepreneurship Programmes in Developing Entrepreneurship Skills towards Quality TVET Graduates
}

\author{
Affero Ismail ${ }^{*}$, Wan Nurashida Adnan ${ }^{2}$, Alias Masek ${ }^{3}$, Razali Hassan ${ }^{4}$, Suhaizal \\ Hashim $^{5} \&$ Mohd Erfy Ismail ${ }^{6}$
}

${ }_{1,2,3,4,5,6}$ Faculty of Technical and Vocational Education, Universiti Tun Hussein Onn Malaysia, Parit Raja, 86400 Batu Pahat, Johor, MALAYSIA

DOI: https://doi.org/10.30880/jtet.2019.11.01.010

Received $10^{\text {th }}$ September 2018; Accepted $03^{\text {rd }}$ November 2018; Available online $31^{\text {st }}$ March 2019

\begin{abstract}
Engagement in self-employment has been emphasised by many TVET institutions as one of the employability criterion in determining the quality of TVET graduates. Series of entrepreneurship programmes has been designed to develop student's skill in strategizing the steps for future plan after graduation, but the impact has not yet been evaluated. Therefore, this study was conducted to investigate the relationship between student's perception of the effectiveness of entrepreneurship programmes and entrepreneurial skills in a Malaysian Public University. A quantitative survey study was designed using questionnaires. A total of 300 undergraduates' students were randomly selected as the respondents. The data were analysed using descriptive statistics including frequency, percentage and mean aided by the Statistical Package for Social Sciences (SPSS) 22. The research findings showed that students' perceptions of the effectiveness of entrepreneurship programmes has a positive moderately correlation to students perceived of self-entrepreneurial skills development. Thus, these findings have a significant impact on the implementation of the entrepreneurship programmes organised by the university, especially to students. The implementation of these programmes should be disclosed starting students studying from the first year up to the end of their programmes, so the process is not stalled half way and the students can see their effectiveness. This is necessary to design and implement programmes of entrepreneurship development well in order to allow the number of entrepreneurs among students increases and establish successful entrepreneurs capable of competing at global level.
\end{abstract}

Keywords: Entrepreneur, entrepreneurship programmes, business, entrepreneurship skills

\section{Introduction}

Making entrepreneurship as a viable skill is a big challenge to TVET institutions and programme providers. Quality TVET graduates has become one of the major shift in Malaysia Education Blueprint 2015-2025 (Higher Education) or MEB (HE) (Ministry of Higher Education Malaysia, 2015). There are ten shifts that drive excellence in the higher education system and shift number four (4) of MEB (HE) focuses on delivering quality TVET graduates. Many initiatives have been taken by Ministry of Higher Education to increase the capacity building especially in developing future workforce. This is in line with European countries that sustain on several models that conduct TVET (Fawcett, Ecsaw, \& Allison, 2014). The first model is liberal market economy where enterprises, have power to describe knowledge and skills relevant to the market. Secondly, it exercises state-regulated bureaucratic model where the government, in France, has power and is responsible for deciding knowledge and skills at TVET institutions. Thirdly, it employs dual system, in Germany, where the two models above are applied leading to public-private partnership in TVET (Fawcett et al, 2014). All of these models are being used in producing quality TVET towards Industrial Revolution 4.0. 
Currently, Malaysia is now on the best track to achieve its goal as a high-income, inclusive and innovative developed nation (The World Bank, 2018). In the context of community and economic development, it creates entrepreneurs and encourages entrepreneurship among the people in general, and among students (Mustafa, Kadir, Akmaliah, \& Pihie, 2013). However, there are issues and challenges in the development of entrepreneurship among TVET graduates that need to be addressed. Despite the increase in entrepreneurship activities and programmes at the university, these activities and programmes are often being implemented beyond the curriculum. This causes difficulty for students to balance time between academic needs and entrepreneurial activities (Adam, Abdul Razak, \& Abu Bakar, 2011). The absence of a guideline for applying entrepreneurial elements and values across the curriculum also makes it difficult to be implemented more effectively (Mahmud, \& Hamzah, 2011).

In addition, engagement and participation among academics, researchers and administrators are still at a low level (Nasharudin, \& Harun, 2010). According to Sidal (2014), various factors have been identified as a possibility that contributes to this imbalance. Among them is the contribution to entrepreneurial activities and programmes not to merit or be regarded as contributing to the promotion of staff either academics or administrators. Entrepreneurship is also understood and seen from a narrow perspective as an effort to encourage students to open and do business solely and not as a learning process that can create a more practical, creative and innovative human being (Miaat, 2014).

Meanwhile, the dependency on government funds for entrepreneurship activities and entrepreneurship programmes in Malaysia remains high (Omar, Rahim and Salman, 2015). Despite the efforts of local institutions to generate their own income as outlined under Higher Education Institution (HEI) Entrepreneurship Strategic Plan 2013-2015, they are still at a minimum when compared to HEIs in developed countries such as the United States and Germany.

Literature has provided evidences on the impact of entrepreneurship programme on students' entrepreneurial skills. For example, in Jain and Chaudhary (2017) study, the survey study indicating the positive impact of entrepreneurship programme on students entrepreneurship skills. However, Jain and Chandhary (2017) study indicated that an entrepreneurship programme has a negative impact on students' entrepreneurial intention. In Bandera and Passerini (2018) study, the integration of entrepreneurship education with Information and Communication Technology (ICT) enhanced students' technology skills especially in communication technology. In Lyons and Zhang (2017), entrepreneurship programme has positive impact on minorities especially females. According to Roslo (2013), although there is a consistent increase in the number of graduates who venture into entrepreneurship as soon as they graduate, the percentage is still very small, about $2 \%$ of the total number of graduates each year. This data is consistent with the 2014 Global Entrepreneurship Monitor (GEM) report that only $50.37 \%$ of Malaysians see entrepreneurship as a good career choice. This phenomenon is possible to limit the tendency of young people to venture into entrepreneurship as a career, especially when it comes to opposition from parents and families.

There is no single definition that could indicate the meaning of entrepreneur (Henry, Hill and Leitch, 2005). There are different schools of thoughts with different definition of entrepreneur. According to Bruyat and Julien (2000), entrepreneurship is seen as a change process, that results in the creation of new values and entrepreneur as business founder. Schumpeter (1911) sees an entrepreneur as an individual who introduces new products and new services, or creates new forms of organisation, or exploits new raw materials while Hamilton and Harper (1994) define an entrepreneur as a person who takes certain level of risks in order to capitalise on an invention. Despite the various definition of entrepreneurship, there are common agreement that entrepreneur is someone with the unique instinct to see change as an opportunity for value creation (Rahim et al., 2015). They also agree that entrepreneurs are idealistic, able to conceptualise and realised the business plans into reality and possessed good characteristic as an entrepreneur.

\section{Methodology}

This study is based on quantitative survey design with a total of 300 respondents out of 1450. Sample were amongst Malaysian Technical Universities Network (MTUN). 75 respondents were selected from each of the MTUN respectively. The data collection was conducted through a self-administered questionnaire survey. A set of questionnaire forms was developed as an instrument consisting of four major parts. Part A relates to respondents' information and background among students. A total of five questions were raised to respondents including gender, years of study, race, specialisation, as well as involvement of respondents in entrepreneurship programmes.

Part B identifies the level of entrepreneurial skills among students. Entrepreneurship skills consists of five skills namely communication skills, thinking skills, information technology skills, time management skills and planning skills adapted from Chatterjee and Das (2016). Each skill was represented by five questions. A total of 25 items were used to gauge students' entrepreneurial skills.

Part C identifies respondents' perceptions on the effectiveness of entrepreneurship programmes after the students' participation. A total of 15 questions are presented in this section. Measurement of data in sections $\mathrm{B}$ and $\mathrm{C}$ is based on five-degree Likert scale ( $1=$ strongly disagree to $5=$ strongly agree). The questionnaire internal reliability was tested using Cronbach's Alpha $(\alpha)$, the value was 0.89 indicating a high reliability and an appropriate indicator for a research study (Hair, Ringle \& Sarstedt, 2011). The data were analysed using descriptive statistics using frequency, mean and standard deviation, while the relationship was performed using Pearson Correlation test. 


\section{Results}

Data analysis indicated that the gender proportion was imbalance with $37 \%$ of male and $63 \%$ of female student. Majority were students from engineering background with $72 \%$. Most of the respondents have at least attend one entrepreneurship programme conducted by the institutions. Further analysis of Part B indicated that the highest skill falls to communication skill with a mean score (M) of 4.76 and Standard Deviation (SD) at 0.87. Meanwhile, management skills is the lowest rated items by students with mean score of 4.35 and $\mathrm{SD}=0.78$. Table 1 shows the level of entrepreneurship skill among respondents.

Table 1 - Student's Entrepreneurship Skill

\begin{tabular}{lcc}
\hline Entrepreneurship Skill & Mean & SD \\
\hline Communication skill & 4.76 & 0.87 \\
Thinking skill & 4.64 & 0.78 \\
Information technology skill & 4.67 & 0.81 \\
Time management skill & 4.35 & 0.78 \\
Planning skill & 4.54 & 0.83 \\
\hline
\end{tabular}

The respondents were asked about the effectiveness of entrepreneurship programme that they have attended with a fivepoint Likert scale. From Table 2, the mean and interpretation for each of the items are tabulated. The item that shows the highest mean score, $\mathrm{M}=3.99$ and $\mathrm{SD}=0.79$ is "Interacting with corporate companies like AYAMAS". A total of 69 respondents, $22.8 \%$ of respond rated "strongly", meanwhile 178 respondents, $58.9 \%$ have indicated their agreement to this item.

The second highest mean score is $\mathrm{M}=3.94$ with $\mathrm{SD}=0.79$, sound like "Identifying the types of businesses that received public response". While the third highest mean is represented by item "Establish business with other entrepreneurs" with a mean $\mathrm{M}=3.90$ and $\mathrm{SD}=0.76 \mathrm{X}$.

However, the item that records the lowest mean score is the item which states "Training to improve communication to customers" with a mean score of $\mathrm{M}=3.50$ and $\mathrm{SD}=1.20$. A total of 42 respondents indicated their disagreement by ticking on the "very disagree", 15 respondents answered "disagreed" and 33 respondents answered "uncertainly". The results are shown in Table 2.

Table 2 - Effectiveness of Entrepreneurship Programme

\begin{tabular}{clccc}
\hline No & \multicolumn{1}{c}{ Item } & Mean & SD & Interpretation \\
\hline 1. & Explore business opportunities & 3.68 & 0.94 & Average \\
2. & Generate ideas through products & 3.78 & 0.91 & Average \\
3. & Generate ideas through service & 3.63 & 0.91 & Average \\
4. & Establish business network with other entrepreneurs & 3.90 & 0.76 & High \\
5. & An alternative career path & 3.85 & 0.79 & High \\
6. & Formulate business planning & 3.65 & 0.89 & Average \\
7. & Build a Business Site & 3.72 & 0.86 & Average \\
8. & Disclosure of marketing opportunities through the Small & 3.80 & 0.88 & High \\
9. & Medium Industry (SMI) & & & High \\
10. & Training to improve communication to customers & 3.94 & 0.79 & Average \\
11. & Produce social media design & 3.50 & 1.20 & Average \\
12. & Interact with companies corporate like AYAMAS & 3.64 & 1.02 & High \\
13. & Information on organisational structure Business. & 3.99 & 0.79 & High \\
14. & Master the basis of planning Business & 3.81 & 0.96 & Average \\
15. & Applying theory of principles & 3.63 & 0.96 & High \\
\hline
\end{tabular}

The relationship between entrepreneurship skills and students' perceived of entrepreneurial programme effectiveness on the questionnaire are shown in Table 3. 
Table 3 - The relationship between entrepreneurial skills and the students' perceived effectiveness of Entrepreneurship Programme

\begin{tabular}{lcc}
\hline Pearson Correlation & Significant & Pearson, $\mathbf{r}$ \\
\hline Communication skill & 0.00 & 0.538 \\
Thinking skill & 0.00 & 0.602 \\
Information technology skill & 0.00 & 0.453 \\
Time management skill & 0.00 & 0.624 \\
Planning skill & 0.00 & 0.731 \\
Entrepreneurship skills & 0.00 & 0.643 \\
\hline Probability value of $p=0.05$. & &
\end{tabular}

The value of ' $p$ ' is 0.00 which is lower than the set ' $p$ ' value of 0.05 . The null hypothesis is rejected and therefore, there is a significant relationship between student's entrepreneurship skill and the students' perceived effectiveness of entrepreneurship programme. It can be seen that the strength of the relationship between the students' perceived effectiveness of entrepreneurship programmes with entrepreneurship skills is moderate $(r=0.643)$. Positive correlation coefficient (r) shows the correlation in a direct relationship.

\section{Findings and Discussion}

Considering the results, the entrepreneurial programme has affected the students' perceived behavioural control and attitudes toward entrepreneurial skill. The literature underlines the relation between these factors and intention, in particular between intention and the perception of communication skill, thinking skill, time management skill and planning skill (Zhao, Hills, \& Seibert, 2005). This study findings indicated that communication skills are one of the most important skills in order to success in entrepreneurship. This is in line with the study from Mohd Salleh, Sulaiman, Mohamad and Sern (2017), communication skills were amongst the skills that are crucial for students to breach into the job market. Therefore, students and educator must focus on the development of communication skills (Ismail, Nasir, Hassan, \& Masek, 2015), along with other skills including thinking skills, planning skills, and management skills.

In responding to the needs of these skills to be nurtured within entrepreneurship programme, several institutions have reviewed their entrepreneurship programmes aligning to current demands. Interestingly, this study findings indicates that students can interact with corporate companies who organized entrepreneurship programmes. This finding also indicated that the entrepreneurship programmes were successful to nurture entrepreneurship skills. This study findings support previous research from several authors (Jain \& Chaudhary, 2017; Henry \& Lewis, 2018), indicating the positive impact of entrepreneurship programme on students' entrepreneurship skills.

Meanwhile, the level of entrepreneurial skills among students after attending entrepreneurship programmes is at medium and high levels. In the entrepreneurial skills section, students master the information technology skills. This is in line with several literature. For example, Bandera and Passerini (2018) integrating entrepreneurship education with Information and Communication Technology (ICT), in order to enhance students' technology skills especially in communication technology. In the $21^{\text {st }}$ century, in line with the industrial revolution 4.0 , digital economic has been growing tremendously, technology skill is a vital skill to survive in the future business. An online entrepreneur will be dominating a major market business in the future in line with the emerging demands of online consumers. Integrating technology in entrepreneurship education is necessary and the move should be initiated from this point.

On the other hand, the entrepreneurship programme does not seem to affect the students' average entrepreneurial intention in the short term. In case of minorities, such as in Lyons and Zhang (2017), entrepreneurship programme has positive impact on short run. The moderate relationship between entrepreneurship skills and the effectiveness of the entrepreneurship programme shows the correlation between these variables. This study findings are in contradictory with findings from Jain and Chaudhary (2017), the entrepreneurship education has negative impact on students' entrepreneurial intention. By looking into several predictors of the programme's design, the result should have to be more positive output to be seen in the future. Entrepreneurship is deemed important in the transformation of nations, politically and socio-economically (Matlay, 2005). Recognising the importance of entrepreneurship education in promoting entrepreneurship development and the economy, Malaysia Ministry of Education has taken the initiative by making entrepreneurship subjects compulsory to all students at the nation public universities (Rahim et al., 2015). The results of this study can lead to less unemployed graduates and an increase in business opportunities, which will have a direct impact on achieving the developed nation status as envisioned by Malaysians. There are not only becoming the job fillers but also the job creators for the future graduates. 


\section{Conclusion}

This study explored the relationships of entrepreneurship skills for students who attended the entrepreneurships programme. Since the respondents has not yet been graduated, students perceived of programme effectiveness was evaluated and were correlated to their entrepreneurship skills. The result indicated that a moderate correlation exists. Therefore, the entrepreneurship programmes need to be designed carefully in incorporating these skills in the training. Students need coherent support for each stage of their studies (Ismail, Hassan, \& Masek, 2015). The programme is suitable to be expanded to students in various level and field of study. However, more efforts are needed in order to improve entrepreneurship programme at higher education level, to be more close industry involving an actual entrepreneur as a role model, personal coaching, special invitation of guest lecturer, and their involvement in the programme design. The outcome of this study can be used as a guideline by prospective researchers, lecturers, stakeholders and the government in the effort to generate more entrepreneurship among students. Thus, the TVET institutions is enable to produce quality TVET graduates for the nation's transformation process especially in creating job makers.

\section{Acknowledgment}

The authors would like to appreciate the Research Centre Management, Universiti Tun Hussein Onn Malaysia for supporting this research. Special thanks also dedicated to all research members and personnel for continuous effort in completing and contributing input for this research.

\section{References}

Adam, A., Abdul Razak, S. \& Abu Bakar, M. H. (2011). Kecenderungan Pelajar-Pelajar Semester Akhir Kolej Komuniti Jasin Terhadap Keusahawanan (Jasin Community College final years students' trend on entreprenships). Mini Seminar Pendidikan Kolej Komuniti Jasin.

Bandera, C. \& Passerini, K. (2018). Risky business: experiential learning, information and communications technology, and risk-taking attitudes I entrepreneurship education. The International Journal of Management Education, 16 (2), $224-$ 238.

Bruyat, C. and Julien, P.A. (2000). Defining the field of research in entrepreneurship. Journal of Business Venturing, 16 (2), 165-80.

Chatterjee, N., \& Das, N. (2016). A Study on the Impact of Key Entrepreneurial Skills on Business Success of Indian Micro-entrepreneurs: A Case of Jharkhand Region. Global Business Review, 17(1), 226-237. https://doi.org/10.1177/0972150915610729

Fawcett, C., Ecsaw, G \& Allison, C. (2014). TVET models, structures and policy reform: Evidence from European and Eurasian regions. United States for development department.

GEM (2014). Global Entrepreneurship Monitor. Global Entrepreneurship Research Association. London Business School. Website: www.gemconsortium.org

Hamilton, R.T. and Harper, D.A. (1994). The entrepreneur in theory and practice. Journal of Economic Studies, 21 (6), $3-18$.

Henry, C. \& Lewis, K. (2018). A review of entrepreneurship education research: exploring the contribution of the education + Training Special issues. Education + Training 60(3), 263-286.

Henry, C., Hill, F. and Leitch, C. (2005). Entrepreneurship education and training: can entrepreneurship be taught? Part 1. Education p Training, 47 (2), 98-111.

Hair, J. F., Ringle, C. M., \& Sarstedt, M. (2011). PLS-SEM: Indeed a silver bullet. The Journal of Marketing Theory and Practice, 19(2), pp. 139-152.

Hardy Loh Rahim, Mohd Ali Bahari Abdul Kadir, Zanariah Zainal Abidin, Junainah Junid, Laila Mohd Kamaruddin, Noor Faizah Mohd Lajin, Siti Zahrah Buyong, Adlan Ahmad Bakri (2015). Entrepreneurship Education In Malaysia: A Critical Review. Journal of Technology Management and Business, 02 (2), 2015 1-11.

Ismail, A., Hassan, R. and Masek, A. (2015). Generating elements of Supervisory Input Support via Exploratory Factor Analysis for effective supervision in Engineering Education. ICEED 2014 - 2014 IEEE 6th Conference on Engineering Education, Kuala Lumpur.

Ismail, A., Nasir, S., Hassan, R. and Masek, A. (2015). Investigating the Roles of Supervisory Working Alliance as Mediator for Overall Supervision Effective Using Structural Equation Modelling. Advanced Science Letters, 21 (5), 1221-1224. 
Jain, S.K. \& Chaudhary, H. (2017). Impact of Entrepreneurship Education on entrepreneurial intentions of potential entrepreneurs in India. Entrepreneurship Education, 289-303.

Lyons, E. \& Zhang, L. (2017). The impact of entrepreneurship programmes on Minorities. American Economic Review 107 (5). doi:10.1257/aer.p20171008

Matlay, H. (2005). Researching entrepreneurship and education: Part 1: what is entrepreneurship and does it matter? Education \& Training, 47 (8/9), 665-77.

Mohd Salleh, K., Sulaiman, N.L., Mohamad, M.M., \& Sern, L.C. (2017). Assessing soft skills components in science and technology programmes within Malaysian Technical Universities. Songkalanakrin Journal of Science \& Technology, $93(3)$.

Mustafa, M., Kadir, S. A., Akmaliah, Z., \& Pihie, L. (2013). Amalan Pengajaran Keusahawanan Dalam Pendidikan Teknik Dan Vokasional. Seminar Pasca Siswazah Dalam Pendidikan, (Greduc), 189-195.

Miaat, E. A. (2014). Faktor yang mendorong kecenderungan pelajar Vokasional ke arah bidang keusahawanan. UTHM. Jurnal Pendidikan.

Ministry of Higher Education Malaysia (2015). Malaysia Education Blueprint 2015-2025. Putrajaya: Malaysia.

Mahmud, S.M., \& Hamzah, R. (2011), Keusahawanan Dalam Pendidikan Teknik dan Vokasional (PTV) di Malaysia, Journal of Edupres, 1, 209-213.

Miaat, E. A. (2014). Faktor yang mendorong kecenderungan pelajar Vokasional ke arah bidang keusahawanan. Jurnal Pendidikan Malaysia.

Nasharudin, N. \& Harun, H. (2010). Aspirasi Kerjaya Keusahawanan dalam Kalangan Pelajar Institusi Pengajian Tinggi Awam. Jurnal Pendidikan Malaysia, 35(1), 11-17.

Omar, F.I., Rahim, S. A., \& Salman, A. (2015). Penyertaan Digital dan ciri keusahawanan dalam pemerkasaan usahawan wanita di Malaysia. Jurnal Komunikasi 31(1).

Roslo, F. B. M. (2013). Pembudayaan Keusahawanan Ke Arah Mempengaruhi Kecenderungan Menceburi Bidang Keusahawanan Dalam Kalangan Bakal Graduan Di UTHM. Zhurnal Eksperimental'noi I Teoreticheskoi Fiziki, 33.

Schumpeter, J.A. (1911). The Theory of Economic Development, Harvard University Press, Cambridge, MA (English translation published in 1934).

The World Bank (2018). The World Bank in Malaysia http://www.worldbank.org/en/country/malaysia/overview

Zhao, H., Seibert, S. \& Hills, G. 2005. The mediating role of self-efficacy in the development of entrepreneurial intentions. Journal of Applied Psychology, 90(6): 1265-1272. 